\title{
Studi Eksperimental dan Simulasi Numerik Karakteristik Aerodinamika Airfoil NACA 4412
}

\author{
Marwan Effendy ${ }^{\mathrm{a}, *}$ dan Muchlisin ${ }^{\mathrm{b}, * *}$ \\ aProgram Studi Magister Teknik Mesin, Sekolah Pascasarjana, Universitas Muhammadiyah Surakarta \\ Jl. Ahmad Yani, Tromol Pos I Pabelan, Surakarta 57102 Indonesia

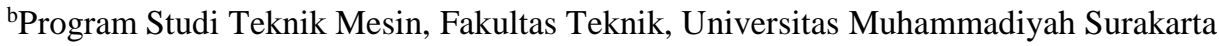 \\ Jl. Ahmad Yani, Tromol Pos I Pabelan, Surakarta 57012 Indonesia \\ *E-mail: Marwan.Effendy@ums.ac.id;**muchlisin.mj@gmail.com
}

\begin{abstract}
The objective of this study is to investigate the aerodynamics characteristic of airfoil NACA 4412 based on experiment and numerical simulation. A 3D airfoil with chord length $(C)$ of $100 \mathrm{~mm}$ and span-width (S) of $200 \mathrm{~mm}$ was fabricated in order to be tested by subsonic wind tunnel at inlet air velocity of $10 \mathrm{~m} / \mathrm{s}$, whereas numerical study was realised by $2 D$ airfoil reffering to geometrics in the experiment. The structured mesh with 810,000 elements number was constructed by Gambit meshing tools up to reach the near wall resolution of $\Delta y+=17.2$. Spallart-Almaras turbulence model was applied in the simulation of RANS study.The effect of various angle of attack $(\alpha)$ between -5 and 20 was investigated for both methods in terms of the aerodinamic characteristics such as lift coefficient $\left(C_{L}\right)$, drag coefficient $\left(C_{D}\right)$, and lift-drag ratio $(L D)$. The pressure coefficient $\left(C_{P}\right)$ and flow visualisations around the airfoil were generated by simulation method. In general, the results show that the data resulted by both methods agree well compared to the other studies, mainly for the lift and drag coefficients. Both coefficients increase with rising the angle of attack before approaching a stall condition at $\alpha=15^{\circ}$. From this point, lift coefficient drops significantly due to large turbulent wake that reduces to lift and influence to drag. The change of attack angles influences the shifting of both stagnation and expansion points in the leading edge, furthermore it causes the overall aerodynamic characteristics. The increase of pressure difference between upper and lower surfaces of airfoil body causes the rise of lift.
\end{abstract}

Keywords: Lift coefficient; drag coefficient; NACA 4412; angle of attack; reynolds average navier stokes

\section{Abstrak}

Penelitian ini bertujuan untuk menyelidiki karakteristik aliran di sekitar profil airfoil NACA 4412 dengan eksperimen dan simulasi numerik. Spesimen uji tiga dimensi dari bahan kayu balsa dengan panjang chord 100 $\mathrm{mm}$ dan lebar span $200 \mathrm{~mm}$ dibuat dalam skala laboratorium untuk keperluan pengujian pada terowongan angin, sedangkan simulasi direalisasikan dengan geometri airfoil dalam bentuk dua dimensi. Sejumlah 810.000 elemen bujursangkar dengan nilai $\Delta y+$ hingga 17,2 berhasil dibuat untuk mencapai tingkat keakuratan hasil simulasi keadaan tunak berbasis Reynolds Average Navier Stokes (RANS). Penyelidikan karakteristik aerodinamika dilakukan pada sudut serang $(\alpha)$ antara $-5^{\circ}$ dan $20^{\circ}$ dengan kecepatan udara $10 \mathrm{~m} / \mathrm{s}$. Beberapa parameter penting seperti koefisien lift $\left(C_{\mathrm{L}}\right)$, koefisien drag $\left(C_{\mathrm{D}}\right)$, rasio lift-drag $(L D)$, koefisien distribusi tekanan $\left(C_{\mathrm{P}}\right)$ serta profil aliran udara di sekitar airfoil diselidiki secara seksama. Hasil penelitian menunjukkan bahwa koefisien hambat $\left(C_{\mathrm{D}}\right)$ dan koefisien angkat $\left(\mathrm{C}_{\mathrm{L}}\right)$ yang diperoleh dengan pendekatan numerik maupun pengujian dalam wind tunnel memiliki kesesuaian dengan data peneliti terdahulu. Seiring dengan peningkatan sudut serang airfoil $(\alpha)$, kedua koefisien tersebut mengalami peningkatan. Penurunan koefisien angkat terjadi secara signifikan pada kondisi stall, yaitu pada saat sudut serang melebihi dari $15^{\circ}$. Perubahan sudut serang berpengaruh terhadap pergeseran titik stagnasi maupun titik ekspansi di daerah leading edge pada permukaan bodi airfoil, yang selanjutnya mempengaruhi karakteristik aerodinamika secara keseluruhan. Semakin besar perbedaan tekanan antara sisi atas dan bawah dari bodi airfoil menghasilkan gaya angkat yang semakin besar.

Kata kunci: Koefisien angkat; koefisien drag; NACA 4412; sudut serang; reynolds average navier stokes

\section{NOMENCLATURE}

C Panjang chord airfoil (chord line)

$C_{\mathrm{L}} \quad$ Koefisien angkat (lift coefficient)

$C_{\mathrm{D}} \quad$ Koefisien hambat (drag coefficient)

$C_{\mathrm{P}} \quad$ Koefisien distribusi tekanan (pressure coefficient)

$V \quad$ Kecepatan udara

$V_{\infty} \quad$ Kecepatan aliran udara (free stream)

$\alpha \quad$ Sudut serang (angle of attack)

$\rho \quad$ Densitas udara (air density) 


\section{Pendahuluan}

Airfoil merupakan suatu konstruksi berpenampang yang memiliki luasan, yang banyak diterapkan diberbagai bidang seperti sayap pesawat, turbin angin, kompresor dan bilah turbin pada mesin jet, propeller blades, hydrofoils, aircraft vertical stabilizers, submarine fins, dan rotary. Bentuk airfoil bisa simetris dan ada juga yang tidak simetris misalnya airfoil NACA 4412 dari National Advisory Committee for Aeronautics (NACA). Geometri airfoil dengan berbagai variasinya umumnya telah memiliki standar pengkodean yang langsung memberikan informasi utama mengenai geometri airfoil.

Secara umum, gaya hambat (drag) dan gaya angkat (lift) dipengaruhi oleh bentuk dan geometri airfoil. Perancangan airfoil yang tepat dapat meminimalkan hambatan yang dihasilkan pada airfoil dan pada sisi yang lain harus mampu memaksimalkan gaya angkat yang besar. Dengan demikian, profil airfoil yang dikehendaki yaitu desain airfoil yang memiliki rasio gaya angkat dan drag $(L / D)$ yang besar. Gaya angkat pada airfoil dihasilkan oleh tekanan negatif yang diciptakan pada bagian permukaan atas airfoil, yang ini dipengaruhi oleh kecepatan udara di sekitar airfoil. Kecepatan aliran dengan bilangan Reynolds rendah umumnya diaplikasikan pada perangkat seperti propeler kapal, sudu turbin gas, sailing aircraft, micro-or-unmanned aerial vehicle (MUAV).

Berkaitan dengan bentuk airfoil NACA 4412, beberapa penelitian pernah dilakukan untuk penyelidikan karakteristik aerodinamika pada geometri sayap pesawat [1][2][3], hidrofoil [4], turbin gas [5], maupun sudu turbin angin [6][7]. Menurut Haque dkk [8], karakteristik dinamis bentuk airfoil memainkan peranan yang sangat penting bagi parameter kinerja seperti koefisien angkat $\left(C_{\mathrm{L}}\right)$, koefisien drag $\left(C_{\mathrm{D}}\right)$, dan rasio lift-drag $(L / D)$.

Beberapa riset tentang karakteristik aerodinamika NACA 4412 di antaranya eksperimen Ahmed dkk [9] yang meneliti efek ground pada airfoil, serta dua simulasi numerik airfoil yang mempertimbangkan efek dynamic ground oleh Qu dkk [10] dan sebelumnya bentuk airfoil dengan flap pada efek extreme ground [11]. Hasil penelitian menunjukkan pentingnya aspek "ground effect" yang mempengaruhi karakteristik aerodinamika airfoil.

Sebuah simulasi numerik airfoil NACA 4412 dengan berbagai variasi "suction pressure" antara $65-80 \mathrm{kPa}$ pada angka Mach 0,6 menunjukkan bahwa airfoil dengan suction pressure lebih efektif untuk mereduksi drag pada sudut serang yang rendah. Pada sudut serang yang tinggi, pemisahan turbulensi di daerah trailing edge akan tertunda dengan adanya suction sehingga bisa lebih efektif.

Berdasarkan beberapa uraian literatur di atas, penelitian ini berfokus pada investigasi karakteristik aerodinamika airfoil NACA 4412 dengan melakukan ekserimen pada subsonic wind tunnel dan simulasi numerik. Simulasi dikerjakan dengan memodelkan airfoil 2D, mesh terstruktur dan model turbulensi Spalart Allmaras (SA) dengan memvariasikan sudut serang antara $-5^{\circ}$ hingga $20^{\circ}$ dengan kecepatan aliran $10 \mathrm{~m} / \mathrm{s}$. Hasil pengujian dengan kedua metode pendekatan, selanjutnya dibandingkan terhadap data-data penelitian yang ada seperti Coles dan Wadcock [3], Haque dkk [8], maupun Abbott dan Doenhoff [12]. Parameter yang digunakan sebagai karakteristik aerodinamika di antaranya koefisien angkat $\left(C_{\mathrm{L}}\right)$, koefisien drag $\left(C_{\mathrm{D}}\right)$, dan rasio lift-drag $(L / D)$, dan koefisien distribusi tekanan $\left(\mathrm{C}_{\mathrm{P}}\right)$.

\section{Metode Penelitian}

Ada dua cara yang dilakukan dalam mengevaluasi karakteristik aerodinamika airfoil NACA 4412 pada penelitian ini, yaitu eksperimen dan simulasi. Kedua cara mempergunakan geometri spesimen uji yang serupa meskipun berbeda dimensinya, yaitu 3D untuk eksperimen dan 2D untuk simulasi. Sebagai acuan dalam pembuatan spesimen uji dan domain simulasi, Gambar 1 merupakan bagian-bagian dari airfoil NACA 4412.

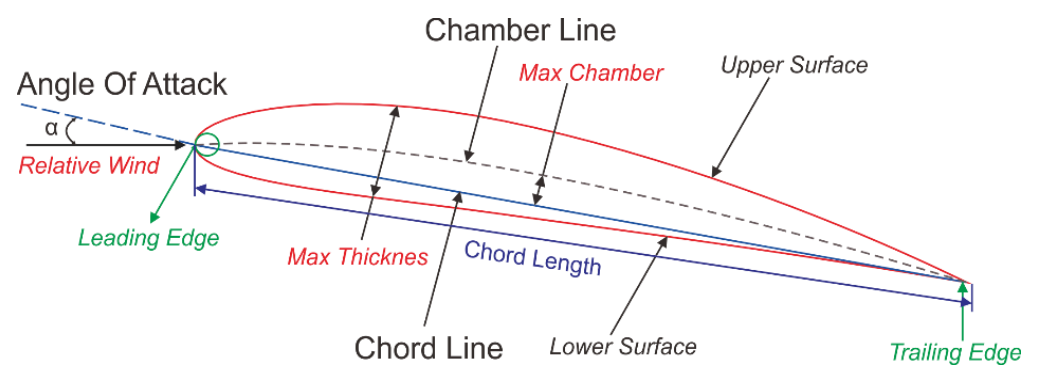

Gambar 1. Spesimen uji

\subsection{Cara Eksperimen}

Spesimen uji NACA 4412 dibuat dari bahan kayu balsa dengan mengacu pada dimensi geometri Gambar 2a, dengan panjang chord $(C)=100 \mathrm{~mm}$, lebar span $(S)=200 \mathrm{~mm}$, ketebalan maksimum $(t)=12 \mathrm{~mm}$. Ilustrasi hasil fabrikasi dan dimensi spesimen airfoil seperti ditunjukkan pada Gambar 2b. Proses finishing hanya dikerjakan dengan mempergunakan amplas halus untuk mencapai tingkat kekasaran pada dinding airfoil. Pada bagian tengah dari chord diberi dudukan penyangga dengan jeruji untuk keperluan eksperimen dalam terowongan angin. 


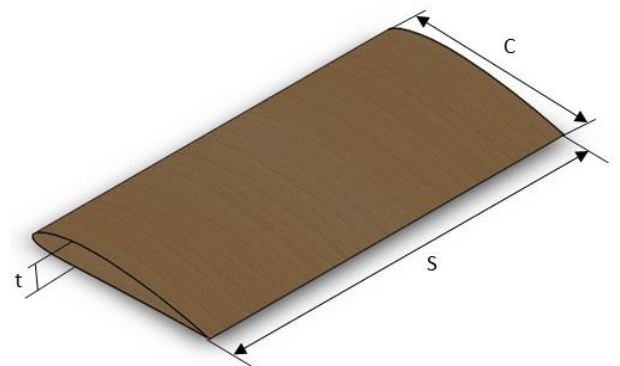

a. Geometri airfoil

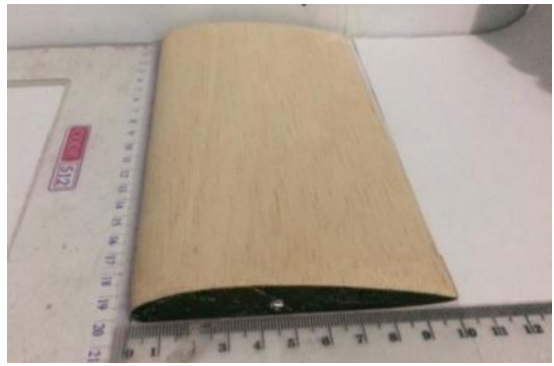

b. Spesimen uji NACA 4412 dari kayu balsa

Gambar 2. Spesimen uji

Percobaan dilakukan dalam terowongan angin (subsonic wind tunnel) di laboratorium Mekanika Fluida, Program Studi Teknik Mesin, Universitas Gadjah Mada (lihat Gambar 3). Terowongan angin memiliki square test section 340 $\mathrm{mm}$ x $450 \mathrm{~mm}$ dan kecepatan maksimal $26 \mathrm{~m} / \mathrm{s}$. Pada proses pengambilan data gaya angkat dan drag, kecepatan angin dalam terowongan pada kecepatan $10 \mathrm{~m} / \mathrm{s}$, sementara sudut serang $(\alpha)$ diatur antara $-5^{\circ}$ dan $20^{\circ}$. Percobaan diulang untuk beberapa variasi tersebut dengan mempertahankan pada tekanan dan temperatur ruang yang sama, yaitu $\mathrm{P}=1$ atm dan $\mathrm{T}=27^{\circ} \mathrm{C}$.

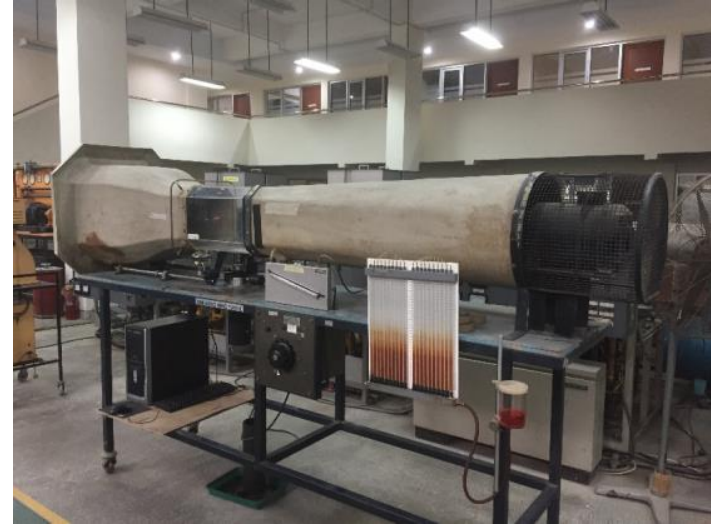

(a) Terowongan angin

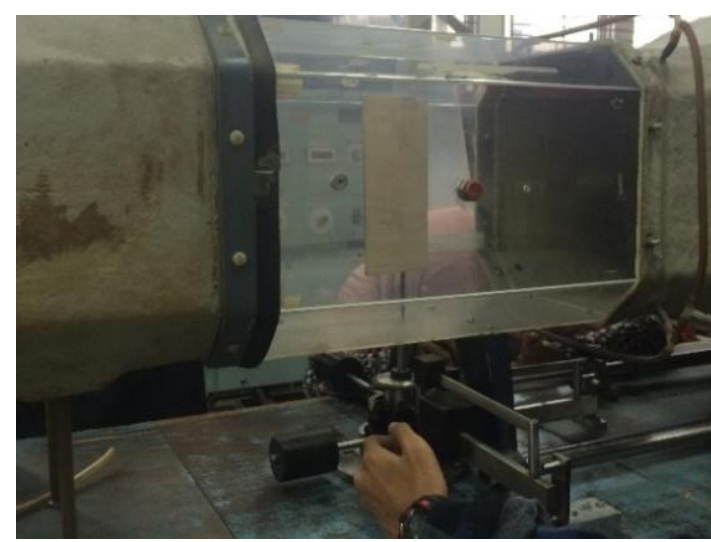

(b) Penempatan spesimen uji

Gambar 3. Subsonic wind tunnel

\subsection{Simulasi Numerik}

Dengan mengacu geometri spesimen uji pada cara eksperimen, simulasi diawali dengan mempersiapkan strategi desain mesh 2D bentuk bujur sangkar seperti Gambar 4a. Setelah melalui pembuatan beberapa macam model mesh dari kasar hingga halus, mesh dengan jumlah 810.000 elemen dan 811.800 nodal akhirnya dipilih untuk simulasi dalam studi numerik ini (lihat Gambar 4b). Di daerah dekat dinding airfoil, mesh dibuat lebih rapat dibandingkan daerah yang jauh dari dinding dengan cara mengatur faktor ekspansi (expansion factor) hingga 1.05. Strategi ini dimaksudkan untuk mendapatkan nilai $\Delta y+$ hingga 17,2 di daerah sekitar dinding airfoil sehingga simulasi numerik menghasilkan keakuratan tinggi. Tingkat kehalusan mesh di sekitar dinding airfoil memainkan peran penting terhadap keberhasilan simulasi sebagaimana pernah diterapkan pada kasus yang lain [4][13].

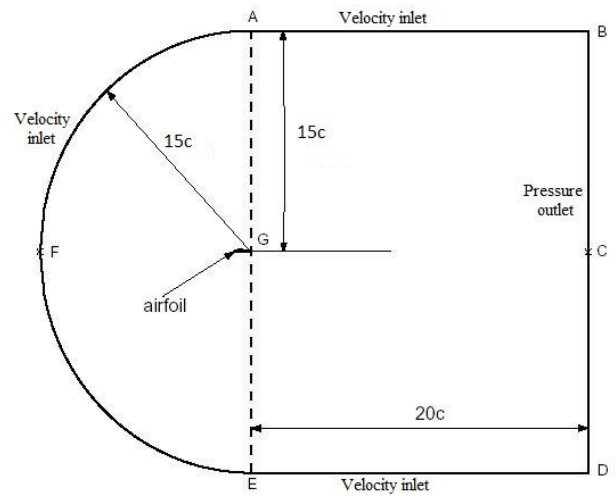

(a) Domain

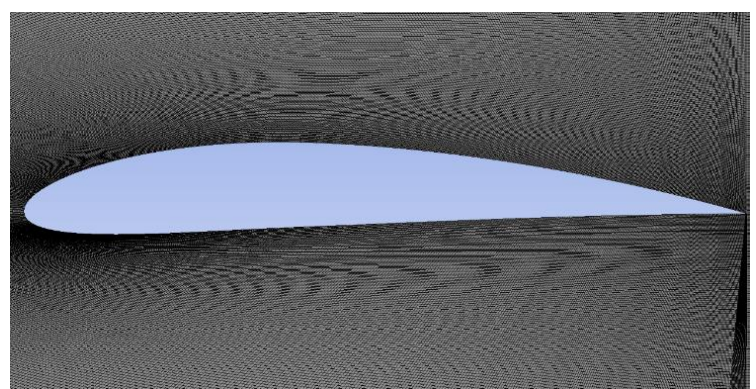

(b) Mesh

Gambar 4. Domain komputasi dan mesh 
Simulasi RANS dilakukan dengan menerapkan model turbulensi Spallart-Allmaras sebagaimana pernah dilakukan Ockfen dan Matveev [11]. Untuk mendapatkan perubahan sudut serang sebagaimana dalam eksperimen, sudut kecepatan perlu diatur pada pendefinisian kondisi batas aliran udara. Simulasi dikerjakan secara berulang-ulang sesuai dengan variasi seperti pada langkah eksperimen.

\section{Hasil dan Pembahasan}

Penelitian secara eksperimen telah berhasil mengidentifikasi koefisien angkat $\left(C_{\mathrm{L}}\right)$ dan koefisien drag $\left(C_{\mathrm{D}}\right)$ airfoil NACA 4412. Untuk melengkapi data penyelidikan, simulasi numerik dengan mengaplikasikan model turbulensi Spallart-Allmaras berhasil memvisualisasi karakteristik aerodinamika aliran di sekitar airfoil selain kedua koefisien tersebut. Koefisien tekanan juga bisa diprediksi untuk melengkapi informasi karakteristik tekanan yang terjadi pada dinding airfoil. Beberapa karakteristik tersebut diuraikan sebagai berikut:

\subsection{Koefisien angkat $\left(C_{\mathrm{L}}\right)$}

Gambar 5 menunjukkan koefisien angkat (lift) antara data prediksi secara simulasi dan data eksperimen pada kecepatan $10 \mathrm{~m} / \mathrm{s}$, dibandingkan dengan data penelitian lain [3][8][12]. Secara umum, $C_{\mathrm{L}}$ hasil eksperimen saat ini memiliki tren yang sama dengan temuan oleh Haque dkk [8], meskipun diakui ada selisih minor pada beberapa posisi sudut serang. Prediksi $C_{\mathrm{L}}$ dari hasil simulasi juga sesuai dengan temuan Abbott dan Doenhoff [12]. Eksperimen Coles dan Wadcock tampak sedikit lebih tinggi pada rentang sudut serang antara $10^{\circ}$ hingga $20^{\circ}$.

Berdasarkan data penelitian yang diperoleh dari eksperimen maupun simulasi saat ini, seiring meningkatnya sudut serang $(\alpha)$ nilai koefisien angkat $\left(C_{\mathrm{L}}\right)$ meningkat sebelum mencapai kondisi stall. Peningkatan koefisien lift secara bertahap ini seiring dengan pergeseran titik pemisahan aliran (separation points) di atas bodi airfoil dan efek turbulensi aliran yang terbentuk sehingga berpengaruh pada hambatan tekanan. Posisi stall terjadi setelah melewati sudut serang $16^{\circ}$ sebagaimana eksperimen yang dilakukan Haque dkk [8] dengan dimensi airfoil yang berbeda. Keadaan stall ditandai dengan penurunan koefisien lift secara drastis. Rendahnya koefisien ini mengindikasikan rendahnya gaya angkat airfoil sebagai efek meningkatnya hambatan tekanan (lihat Gambar 6) karena olakan aliran di belakang bodi airfoil semakin besar (large turbulent wake) seperti ditunjukkan pada Gambar 9f.

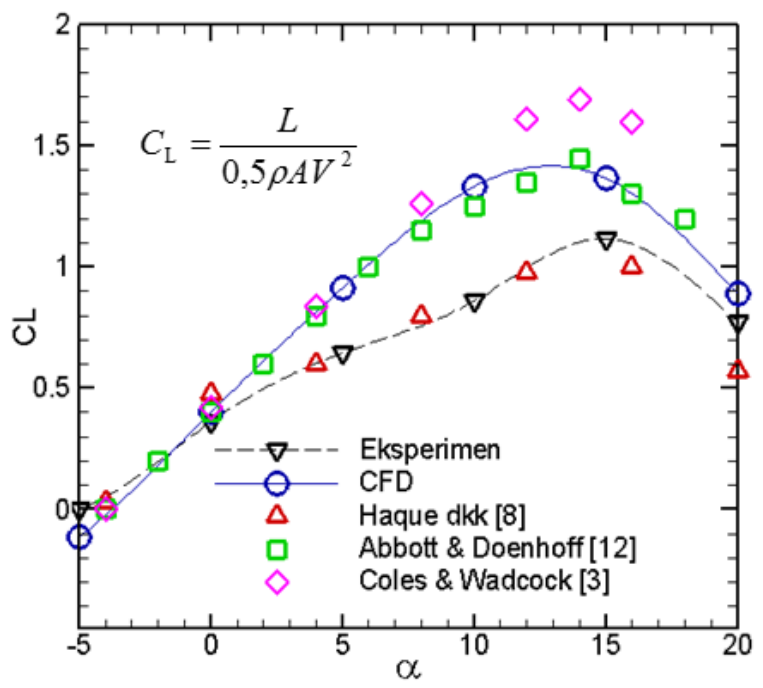

Gambar 5. Koefisien angkat

\subsection{Koefisien drag $\left(C_{\mathrm{D}}\right)$}

Gambar 6 menunjukkan koefisien drag antara data prediksi secara simulasi dan data eksperimen, dibandingkan dengan data penelitian lain. Koefisien drag memiliki tren yang serupa di antara peneliti, meskipun diakui ada selisih pada beberapa posisi sudut serang. Data prediksi cara simulasi memiliki perbedaan hingga 10\% dibandingkan terhadap cara eksperimen dengan tren yang serupa. Koefisien drag meningkat pada sudut serang $0^{\circ}$ hingga $20^{\circ}$, sebagaimana penelitian Haque dkk [8] maupun temuan Abbott dan Doenhoff [12]. Koefisien drag semakin besar dengan melebarnya daerah olakan aliran yang besar di belakang bodi airfoil. 


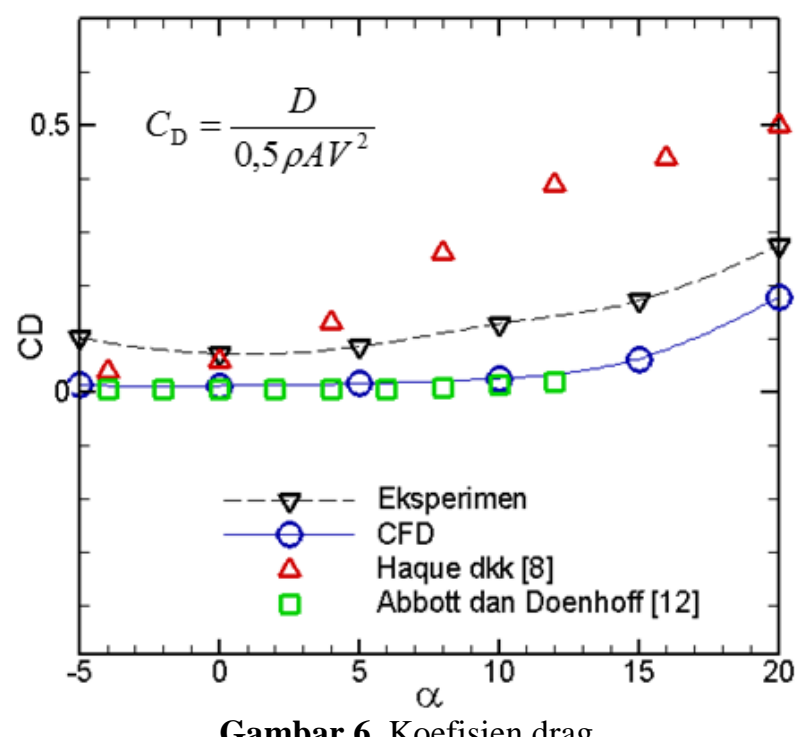

3.3 Rasio lift-drag $(L / D)$

Gambar 7 menunjukkan rasio antara gaya angkat $(L)$ dan gaya drag $(D)$ dari hasil prediksi simulasi numerik dan eksperimen dibandingkan dengan penelitian lain yang serupa. Rasio $L / D$ hasil eksperimen penelitian saat ini konsisten dengan data eksperimen oleh Haque dkk [8]. Perbandingan harga gaya angkat terhadap gaya drag meningkat seiring membesarnya sudut serang dan mencapai harga puncak di sekitar sudut serang 5-10 ${ }^{\circ}$. Hasil ini mengindikasikan bahwa pada sudut serang tersebut memiliki gaya angkat yang besar dan hambatan yang relatif rendah. Rasio $L / D$ mengalami penuruan pada sudut serang yang semakin besar setelah mencapai harga puncak.

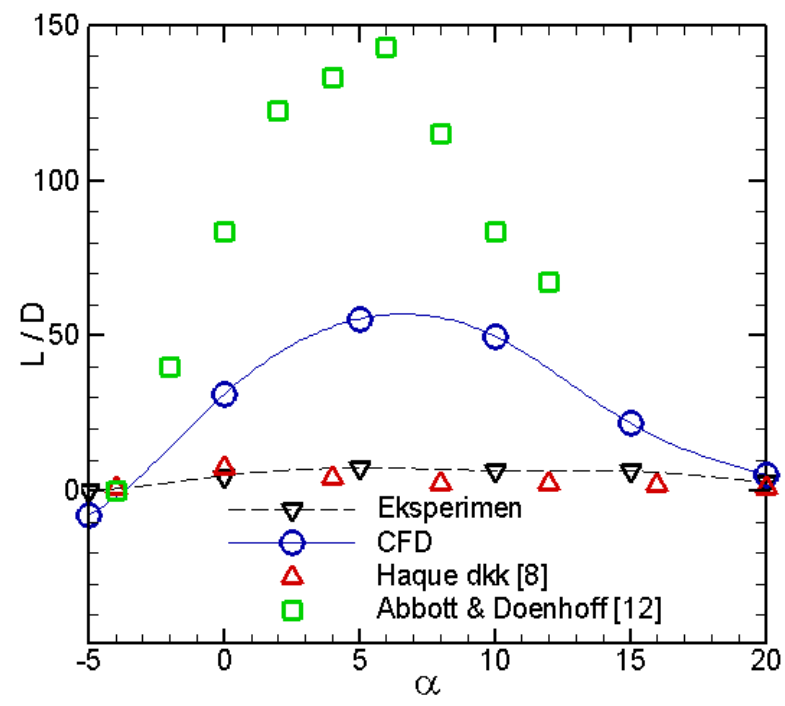

Gambar 7. Rasio lift-drag

\subsection{Koefisien tekanan $(C p)$}

Koefisien tekanan (pressure coefficient) umumnya dipergunakan untuk analisis tekanan, kecepatan dan fenomena aliran di sekeliling airfoil. Perubahan $C_{\mathrm{P}}$ bisa bermanfaat untuk memprediksi seberapa besar akselerasi dan penurunan kecepatan aliran yang terjadi, serta adanya aliran bubble maupun reattachment sebagai akibat gradien adverse pressure yang relatif besar di daerah hilir (downstream).

Gambar 8 menunjukkan koefisien tekanan pada dinding atas airfoil pada berbagai perubahan sudut serang $(\alpha)$ pada kecepatan aliran $10 \mathrm{~m} / \mathrm{s}$. Pada sudut serang negatif $-5^{\circ}$, koefisien tekanan pada dinding atas pada daerah leading edge memiliki tekanan yang lebih besar dibandingkan dengan perubahan sudut serang yang lainnya. Pada sudut serang $0^{\circ}$ koefisien tekanan pada daerah leading edge cenderung menurun hingga pada sudut serang $15^{\circ}$, kemudian pada sudut serang $20^{\circ}$ koefisien tekanan pada daerah leading edge mengalami kenaikan kembali. 


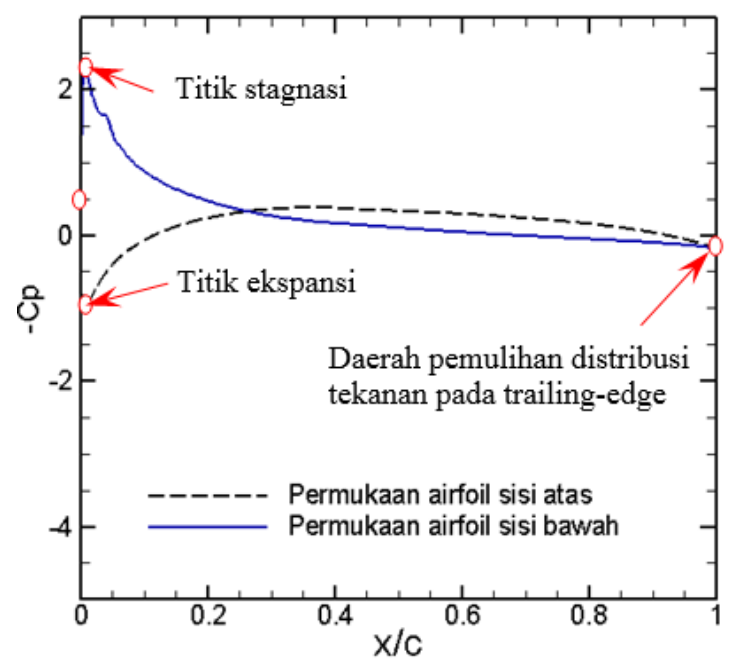

a. $-5^{\circ}$

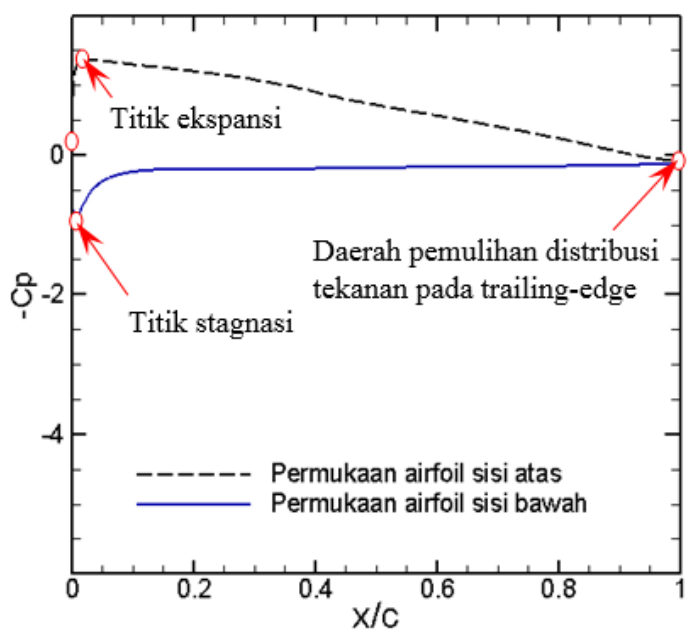

c. $5^{\circ}$

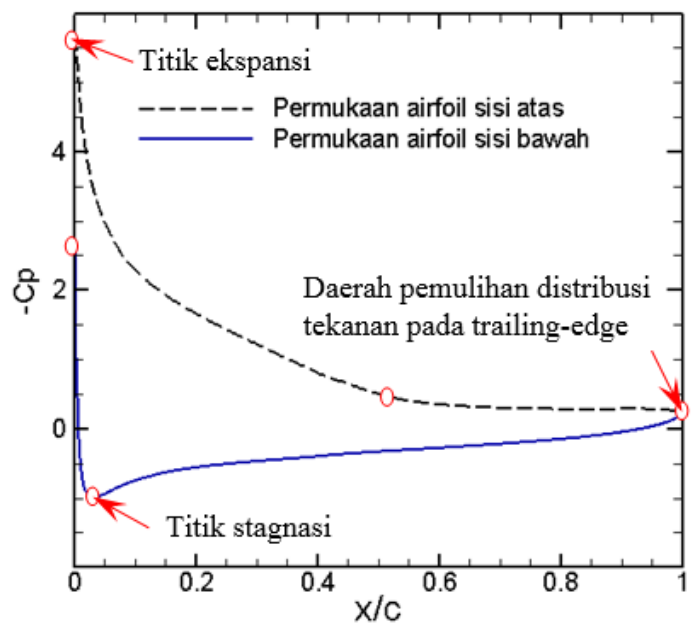

e. $15^{\circ}$

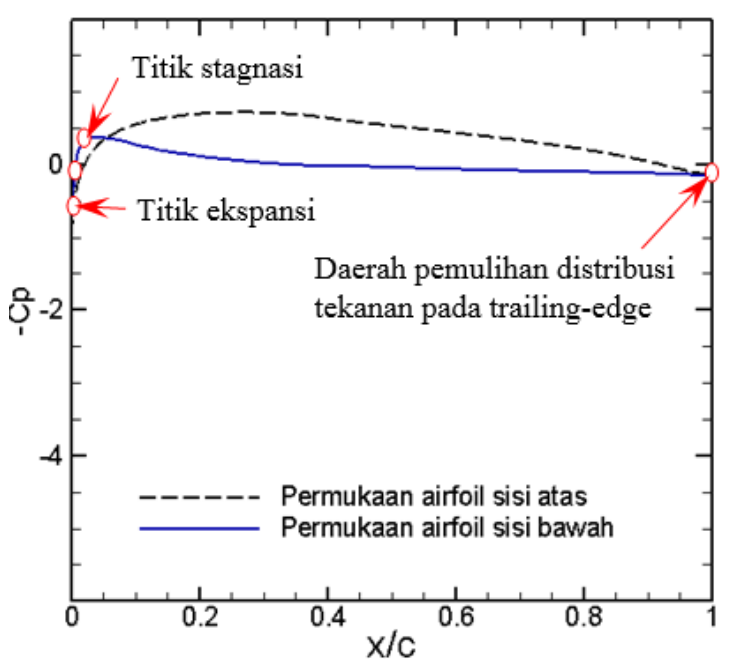

b. $0^{\circ}$

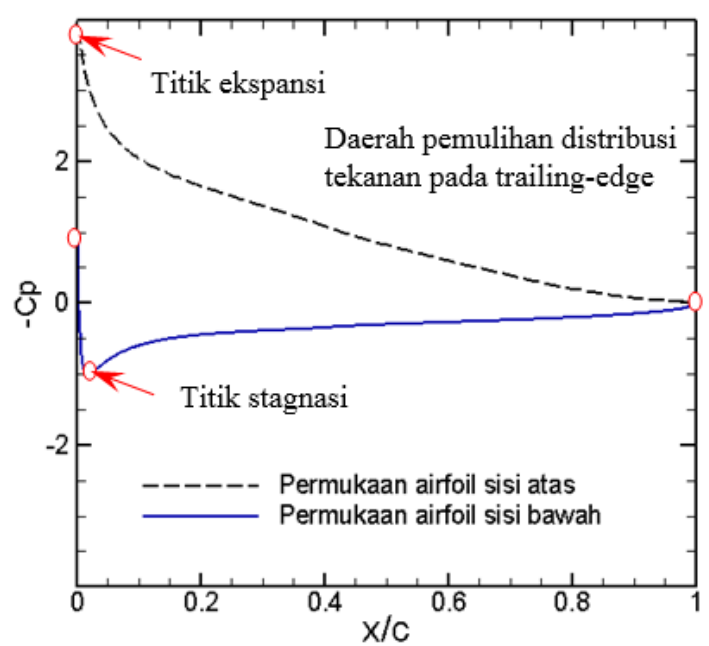

d. $10^{\circ}$

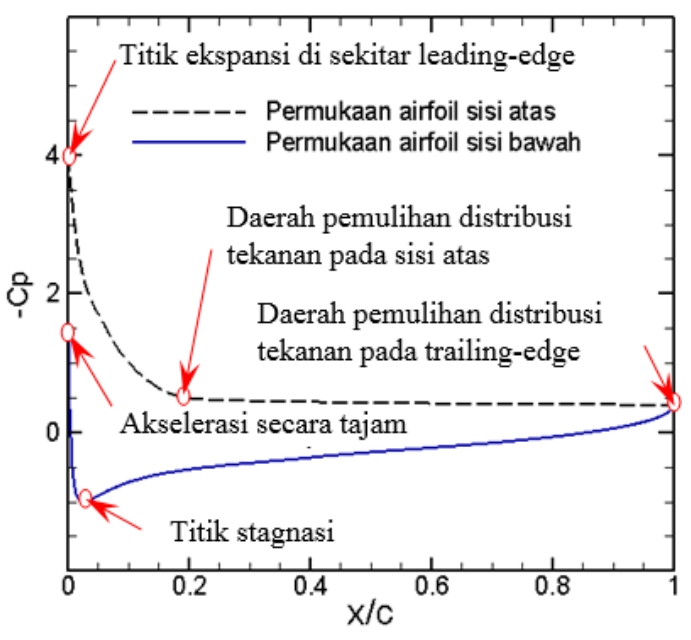

f. $20^{\circ}$

Gambar 8. Koefisien distribusi tekanan

Perubahan posisi sudut serang airfoil yang terjadi karena adanya perubahan sudut datang dari kecepatan aliran udara (free stream), secara langsung merubah letak titik stagnasi maupun titik ekspansi di daerah hulu (leading edge). Penambahan sudut serang ke arah positif mengakibatkan pergeseran titik stagnasi ke arah bagian bawah dari permukaan bodi airfoil, sedangkan titik ekspansi yang berada di sekitar leading edge bergeser ke sisi atas permukaan airfoil. Secara jelas, pergeseran titik stagnasi maupun titik ekspansi pada berbagai posisi sudut serang diilustrasikan 
pada Gambar 9. Titik stagnasi memiliki harga $C_{\mathrm{P}}$ yang tertinggi dengan kondisi kecepatan lokal terendah. Sebaliknya, titik ekspansi memiliki karakteristik $C_{P}$ yang terendah dengan kecepatan lokal tertinggi. Di daerah hidung airfoil (leading edge), akselerasi aliran udara terjadi di antara titik stagnasi dan ekspansi yang ditandai dengan peningkatan $C_{\mathrm{P}}$ secara tajam. Secara ilmiah, gradien tekanan yang tinggi terjadi pada daerah ini sehingga menghasilkan gaya angkat. Di daerah trailing edge, proses pemulihan tekanan terjadi yang ditandai dengan adanya kesamaan harga $C_{\mathrm{P}}$ pada posisi x/c yang sama antara permukaan airfoil sisi atas dan bawah. Gradien tekanan yang rendah terjadi pada saat aliran udara melewati ketebalan maksimum dari profil airfoil, dan hal ini berpotensi mereduksi timbulnya gaya angkat.

\subsection{Profil aliran di sekitar airfoil}

Gambar 9 menunjukkan karakteristik kecepatan aliran di sekitar airfoil pada berbagai sudut serang dengan asumsi kecepatan aliran udara masuk untuk pengujian adalah $10 \mathrm{~m} / \mathrm{s}$. Posisi daerah peningkatan kecepatan aliran berubah apabila ada perubahan sudut serang sebagaimana ditunjukkan bergesernya daerah aliran berwarna merah. Kecepatan aliran yang tinggi terjadi pada daerah di bawah leading edge ketika sudut serang berada pada $-5^{\circ}$, kemudian jika dirubah menjadi $0^{\circ}$ menyebabkan dominasi kecepatan tinggi bergeser di atas bodi airfoil pada bagian tengah dan berdasarkan hukum alam tekanan di daerah berwarna merah ini menjadi lebih rendah sehingga secara keseluruhan terjadi peningkatan gaya angkat (lihat Gambar 6). Posisi titik berkecepatan tinggi akan berada di atas leading edge apabila sudut serang berangsur-angsur terus diperbesar.

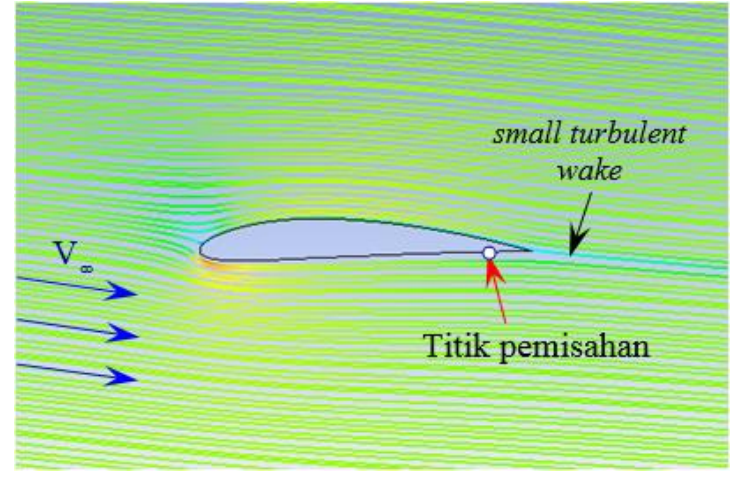

a. $-5^{\circ}$

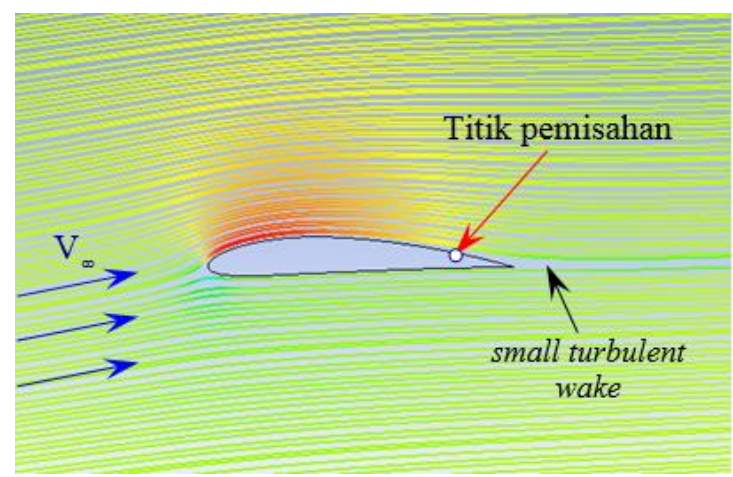

c. $5^{\circ}$

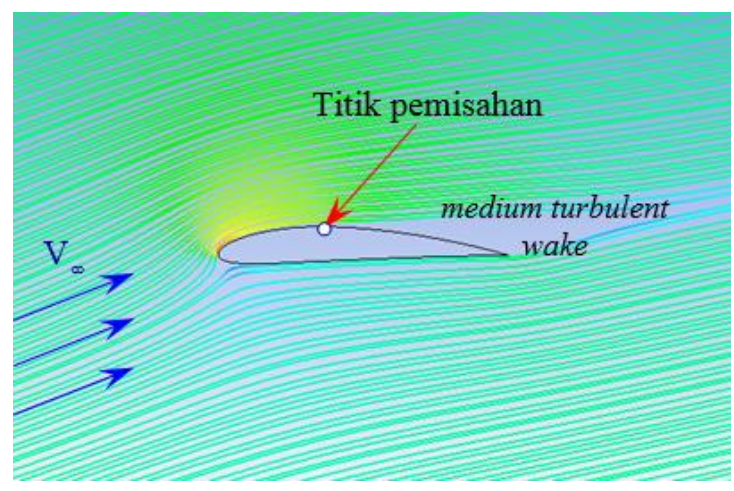

e. $15^{\circ}$

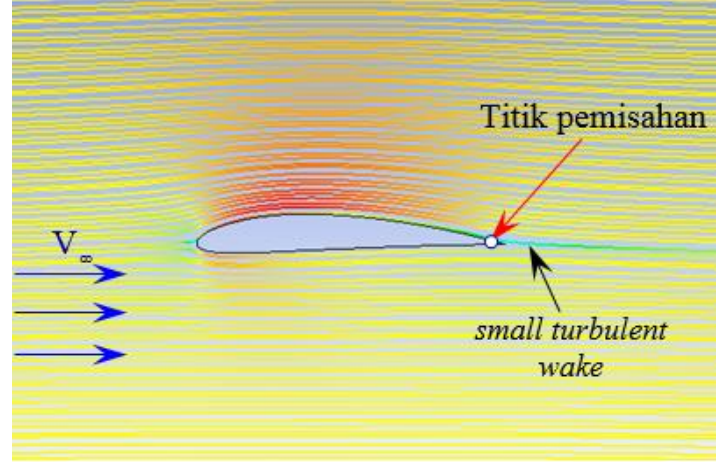

b. $0^{\circ}$

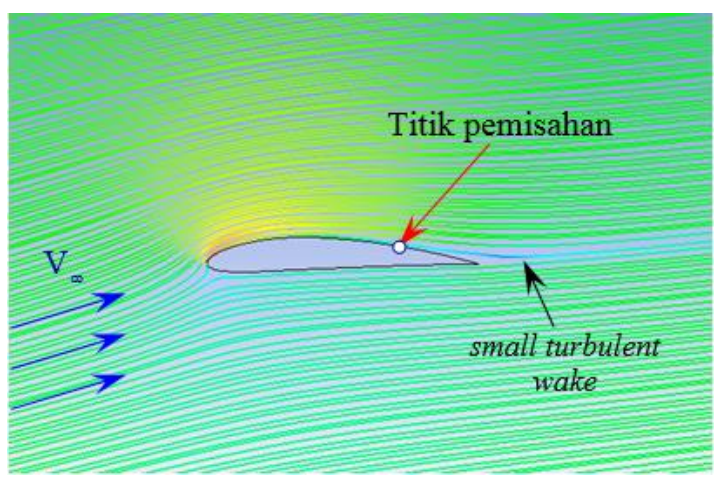

d. $10^{\circ}$

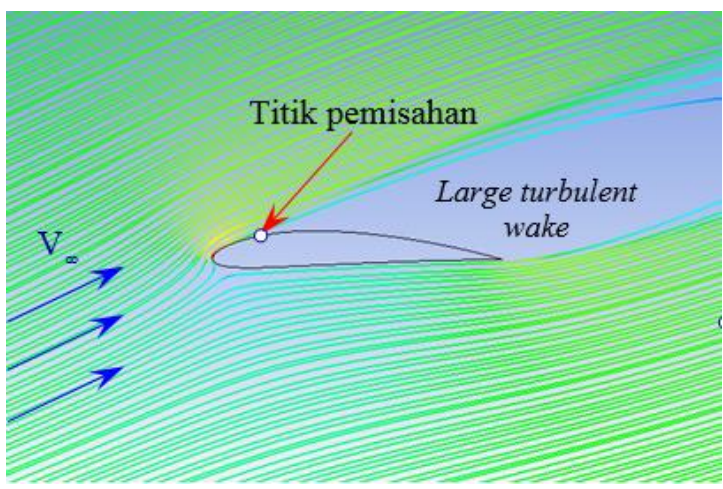

f. $20^{\circ}$

Gambar 9. Karakteristik aliran di sekitar airfoil 
Gambar 9b menunjukkan terjadinya olakan aliran (turbulent wake) tipis pada saat sudut serang $0^{\circ}$ dan titik-titik pemisahan (separation points) berada di sekitar bagian ekor airfoil (trailling edge). Titik-titik pemisahan aliran di belakang bodi airfoil bergeser ke depan secara bertahap seiring dengan membesarnya sudut serang dari $0^{\circ}$ ke $20^{\circ}$. Peningkatan sudut serang menyebabkan aliran di belakang bodi airfoil terjadi turbulensi semakin besar (large turbulent wake), akibatnya gaya angkat tereduksi (reduced lift) dan efek hambatan tekanan membesar (large pressure drag). Dengan meluasnya daerah aliran terpisah tentunya terjadi reduksi gaya angkat seperti penurunan koefisien lift yang tajam dari sudut serang $15^{\circ}$ ke $20^{\circ}$ (lihat Gambar 5). Pada perubahan sudut serang ini memicu terbentuknya vortex shedding pada daerah leading edge dan trailling edge semakin radikal sehingga menyebabkan koefisien lift turun.

\section{Kesimpulan}

Eksperimen dan studi numerik tentang karakteristik aerodinamika airfoil NACA 4412 pada berbagai sudut serang $(\alpha)$ yang berbeda telah berhasil dilakukan pada pengujian dengan kecepatan aliran udara $10 \mathrm{~m} / \mathrm{s}$. Data yang dihasilkan dengan kedua metode memiliki tren yang sesuai dibandingkan terhadap penelitian lain dengan airfoil yang sama. Perubahan sudut serang airfoil memainkan peran yang sangat penting terhadap karakteristik aerodinamika aliran, seperti koefisien lift $\left(C_{\mathrm{L}}\right)$, koefisien drag $\left(C_{\mathrm{D}}\right)$, rasio lift-drag $(L / D)$, koefisien tekanan $\left(\mathrm{C}_{\mathrm{P}}\right)$ dan profil aliran. Perubahan sudut serang berpengaruh terhadap pergeseran titik stagnasi maupun titik ekspansi di daerah leading edge pada permukaan bodi airfoil. Perbedaan tekanan antara sisi atas dan bawah dari permukaan airfoil semakin besar seiring dengan bertambahnya sudut serang. Perubahan sudut serang ke arah positif mengakibatkan bertambahnya akselerasi bagian atas dari daerah hidung (nose) airfoil, sedangkan pada bagian bawah dari daerah hidung airfoil terjadi perlambatan.

\section{DAFTAR PUSTAKA}

[1] R. Azim, M. M. Hasan, and M. Ali, "Numerical Investigation on the Delay of Boundary Layer Separation by Suction for NACA 4412," Procedia Eng., vol. 105, no. Icte 2014, pp. 329-334, 2015.

[2] W. Zhang, W. Cheng, W. Gao, A. Qamar, and R. Samtaney, "Geometrical Effects on the Airfoil Flow Separation and Transition," Comput. Fluids, vol. 116, pp. 60-73, 2015.

[3] D. Coles and A. J. Wadcock, "Flying-Hot-Wire Study of Flow Past an NACA 4412 Airfoil at Maximum Lift," AIAA, vol. 5, no. 4, pp. 321-329, 1979.

[4] I. Uddin and M. Karim, "Application of Volume of Fluid (VOF) Method for Prediction of Wave Generated by Flow around Cambered Hydrofoil," Procedia Eng., vol. 194, pp. 82-89, 2017.

[5] K. Koca, M. S. Genç, H. H. Açıkel, M. Çagdas, and T. M. Bodur, "Identification of Flow Phenomena over NACA 4412 Wind Turbine Airfoil at Low Reynolds Numbers and Role of Laminar Separation Bubble on Flow Evolution," Energy, vol. 144, pp. 750-764, 2018.

[6] A. Vardar and I. Alibas, "Research on Wind Turbine Rotor Models Using NACA Profiles," Renew. Energy, vol. 33, pp. 1721-1732, 2008.

[7] S. Beyhaghi and R. S. Amano, "A Parametric Study on Leading-edge Slots Used on Wind Turbine Airfoils at Various Angles of Attack," J. Wind Eng. Ind. Aerodyn., vol. 175, no. February, pp. 43-52, 2018.

[8] M. N. Haque, M. Ali, and I. Ara, "Experimental Investigation on the Performance of NACA 4412 Aerofoil with Curved Leading Edge Planform,” Procedia Eng., vol. 105, no. Icte 2014, pp. 232-240, 2015.

[9] M. R. Ahmed, “Aerodynamics of a NACA4412 Airfoil in Ground Effect,” AIAA, vol. 45, no. 1, 2007.

[10] Q. Qu, X. Jia, W. Wang, P. Liu, and R. K. Agarwal, "Numerical Study of the Aerodynamics of a NACA 4412 Airfoil in Dynamic Ground Effect," Aerosp. Sci. Technol., vol. 38, pp. 56-63, 2014.

[11] A. E. Ockfen and K. I. Matveev, "Aerodynamic Characteristics of NACA 4412 Airfoil Section with Flap in Extreme Ground Effect," Inter J Nav Arch. Oc Engng, pp. 1-12, 2009.

[12] I. H. Abbott and A. E. V Doenhoff, Theory of Wing Sections Including a Summary of Airfoil Data. Dover Publications, Inc., 1959.

[13] M. Effendy, Y. F. Yao, J. Yao, and D. R. Marchant, "DES Study of Blade Trailing-edge Cutback Cooling Performance with Various Lip Thicknesses," Appl. Therm. Eng., vol. 99, pp. 434-445, 2016. 